\title{
Atlantis
}

Critical Studies in Gender, Culture \& Social Justice

Études critiques sur le genre, la culture, et la justice

\section{Gender, Race, and Precarity: Theorizing the Parallels Between Early Childhood Educators and Sessional Faculty in Ontario}

\section{Zuhra Abawi, Rachel Berman et Alana Powell}

Volume 40, numéro 1, fall 2019

URI : https://id.erudit.org/iderudit/1066420ar

DOI : https://doi.org/10.7202/1066420ar

Aller au sommaire du numéro

Éditeur(s)

Mount Saint Vincent University

ISSN

1715-0698 (numérique)

Découvrir la revue

Citer cet article

Abawi, Z., Berman, R. \& Powell, A. (2019). Gender, Race, and Precarity: Theorizing the Parallels Between Early Childhood Educators and Sessional Faculty in Ontario. Atlantis, 40(1), 45-60. https://doi.org/10.7202/1066420ar
Résumé de l'article

This paper critically examines the parallels of devaluation encountered by early childhood educators and sessional faculty members in Ontario as reflective praxis. The three authors' experiences are diverse and include a tenured professor and two sessional faculty members, both ofwhom have worked in the field of Early Childhood Education and Care (ECEC). The narratives of the authors inform the concerning trend of precarity and devaluation embedded within two polarizing spectrums of the Ontario educational landscape: Post-Secondary Education (PSE) and ECEC. Although these aforementioned areas of education rarely intersect, the authors centre them on the frontline of the neoliberal assault on education transpiring in Ontario today. The three authors self-identify as female settlers; two have doctoral degrees; one has an MA and is an early childhood educator (ECE). One author self-identifies as a racialized and white-coded cis-gendered woman, and two selfidentify as white, cis-gendered women. All of the authors have worked in Ontario's post-secondary landscape, one as sessional faculty member and then a tenured professor, and two as sessional faculty members. The paper will problematize the neoliberal assault on higher education and ECEC through a Feminist Political Economy (FPE) conceptual framework in order to draw on the multifaceted ways femAtlantis Journal Issue 40.1/2019 46 inized discourses devalue the work of ECEs and perpetuate the overrepresentation of women, particularly racialized women in precarious faculty positions.
Ce document est protégé par la loi sur le droit d'auteur. L'utilisation des services d'Érudit (y compris la reproduction) est assujettie à sa politique d'utilisation que vous pouvez consulter en ligne.

https://apropos.erudit.org/fr/usagers/politique-dutilisation/ 


\section{Research}

\section{Gender, Race, and Precarity: Theorizing the Parallels Between Early Childhood Educators and Sessional Faculty in Ontario}

Zuhra Abawi is a Senior Lecturer at Niagara University's College of Education, Ontario Educational Studies. She completed her Doctor of Education in Social Justice Education at OISE/University of Toronto. Zuhra also holds a Master of Education, Bachelor of Education, and Bachelor of Arts in Political Science. Additionally, she has a Diploma in Early Childhood Education and is both an Ontario Certified Teacher and Registered Early Childhood Educator. Her research interests include Critical Race Theory, teacher education, reconceptualist approaches to Early Childhood Education, and educational policy. Zuhra has also worked as an elementary teacher for five years in the Peel District School Board.

Rachel Berman is Graduate Program Director and Associate Professor at Ryerson's School of Early Childhood Studies. Prior to joining the School of Early Childhood Studies, Rachel taught feminist research methods at both York University and McMaster University. Rachel has a $\mathrm{PhD}$ in Family Studies from the University of Guelph and an MA in Human Development and Family Relations from the University of Connecticut. Her research interests include mothering, parenting, family engagement and perspectives of youth and childhood, race and childhood, and critical qualitative inquiry. Rachel is also a member of the Reconceptualizing Early Childhood Education Association, Association for Research on Mothering, the Canadian Sociology Association, and the Women's and Gender Studies et Recherches Féministes, and an adjunct member to the graduate program in Gender, Feminist \& Women's Studies, York University.

Alana Powell is Policy and Special Projects Officer at the Association of Early Childhood Educators of
Ontario. Alana completed her MA in Early Childhood Studies from Ryerson University and is a Registered Early Childhood Educator. Prior to her role at the Association of Early Childhood Educators of Ontario, she was a contract lecturer at George Brown College's School of Early Childhood. Her research engages in critical exploration of care discourses in early childhood and she has played an active role in the Ontario child care advocacy movement for several years.

Abstract: This paper critically examines the parallels of devaluation encountered by early childhood educators and sessional faculty members in Ontario as reflective praxis. The three authors' experiences are diverse and include a tenured professor and two sessional faculty members, both of whom have worked in the field of Early Childhood Education and Care (ECEC). The narratives of the authors inform the concerning trend of precarity and devaluation embedded within two polarizing spectrums of the Ontario educational landscape: Post-Secondary Education (PSE) and ECEC. Although these aforementioned areas of education rarely intersect, the authors centre them on the frontline of the neoliberal assault on education transpiring in Ontario today. The three authors self-identify as female settlers; two have doctoral degrees; one has an MA and is an early childhood educator (ECE). One author self-identifies as a racialized and white-coded cis-gendered woman, and two selfidentify as white, cis-gendered women. All of the authors have worked in Ontario's post-secondary landscape, one as sessional faculty member and then a tenured professor, and two as sessional faculty members. The paper will problematize the neoliberal assault on higher education and ECEC through a Feminist Political Economy (FPE) conceptual framework in order to draw on the multifaceted ways fem- 
inized discourses devalue the work of ECEs and perpetuate the overrepresentation of women, particularly racialized women in precarious faculty positions.

Keywords: Feminist Political Economy, precarious labour, anti-intellectualism, racialization, neoliberalism, education

\section{Introduction}

Across Ontario, the devaluation of women's labour has become increasingly evident among two rarely compared but interrelated fields of education: PostSecondary Education (PSE) and Early Childhood Education and Care (ECEC). In the PSE context, this trend has been marked by the overreliance on sessional lecturers, most of whom are women, despite continuing tuition increases. In the ECEC context, persistently low pay and chronic devaluation of ECEs (a profession also dominated by women), although accompanied by increasing childcare fees for families, has compounded poor working conditions. Both occupations are characterized by the feminization of poverty, low pay, poor working conditions, and limited opportunities for growth. Both arenas are analyzed in this paper through a Feminist Political Economy (FPE) framework in order to determine how social norms, domestic work, and capitalist economies shape women's experiences and determine women's work.

We draw on political, social, and economic underpinnings that characterize the intersectionalities of oppression, including race, gender, social-economic status, that emerge to frame experiences of women's participation in the labour force. While women in both sessional and tenured professoriate positions are expected to take on additional unpaid labour, including mentorship and guidance roles, women working in ECEC are discursively constructed as natural caregivers and substitute mothers (Bezanson 2017; Moss 2006; Nair 2014).

Our objective is to theorize the parallels of devaluation, precarity, and gendered labour implicating the ECEC and PSE fields. This paper is divided into five sections: 1) this introduction, which provides the contextual factors underpinning the issues facing Ontario ECEs and sessional faculty, 2) neoliberalism in Ontario, 3) the conceptual framework of Feminist Political Economy, 4) situating ourselves through our own narratives, and 5) conclusions and discussion. 


\section{Neoliberalism in Education and Childcare}

Ontario has witnessed the unfolding of two trends at both ends of the education spectrum for quite some time. The first involves the steep increases in tuition fees for Ontario students, who now pay the highest tuition fees in Canada, at an average of $\$ 9,500$ a year (Shaker, Macdonald \& Wodrich 2014; Statistics Canada 2019). Ontario students simultaneously receive the lowest per-student funding in Canada (Kirmse 2018). Skyrocketing tuition fees have accompanied severe government cuts in PSE funding, thereby shifting educational responsibility from the state to the individual and thus perpetuating the commodification of higher education (Giroux 2014; Jones \& Field 2014; 2016). Additionally, funding cuts to PSE initiated by the Ontario Progressive Conservative Party in 2018 under the leadership of Premier Doug Ford have increased the financial burden on students. Proposed changes include the erosion of both the Ontario Student Assistance Program (OSAP) and the Province's student loan program, which would effectively remove the six-month grace period before loan repayment.

The second phenomenon concerns the increasing marketization of ECEC in the province (Halfon \& Langford 2015). In addition to having the highest tuition fees in Canada, Ontario also has the most expensive childcare costs in the country (Bezanson 2017). The highest childcare costs are concentrated in Toronto and the Greater Toronto Area (GTA). Childcare fees in Toronto average $\$ 1,758$ a month, or $\$ 21,096$ per year, fees that are coupled with a chronic shortage of licensed, regulated childcare centres. Currently only 20 percent of Ontario childcare facilities are licensed (Kirmse 2018; Mahboubi 2018). The rising cost of living in Ontario has not kept pace with wages and often detrimentally impacts women, as women are forced to choose between working and staying home. This situation thus perpetuates the gendered wage gap (Richardson et al. 2013).

These two trends cannot be divorced from the gendered, racialized, and neoliberal hegemonic power relations from which they are situated. As tuition and childcare costs have swollen to record heights, university professors and ECEs have seen little to no improvements in their pay, benefits, or working conditions. Rather, the marketization of both higher education and ECEC is a result of the lack of a national education strategy as well as a national childcare policy framework that has downloaded social-liberal state responsibilities onto individuals. Government retrenchment from PSE funding has contributed to an overreliance on sessional faculty, or on faculty who often have the same qualifications as their tenured colleagues but are paid on a precarious per-course or per-contract basis (Faucher 2014; Foster 2016; Henry et al. 2017). The marketization of childcare across Ontario due to lack of government investment in social policies such as childcare has individualized family responsibility for funding childcare initiatives. The continued reliance on private funds for childcare translates into higher costs for care and less pay for ECEs, despite increased professional expectations and workloads (Osgood 2010). ECEC continues to be conceptualized as private, feminized, and ultimately a welfare issue, distinguished from Kindergarten to Grade 12 (K-12) publicly funded education (Langford et al. 2017).

The majority of professoriate positions, once regarded as among the most secure positions in Canada, have shifted to a precarious labour pool of highly educated, skilled surplus workers for universities to draw from in order to cut costs (Muzzin \& Limoges 2008; Muzzin \& Meaghan 2014; Shaker \& Pasma 2018). While Ontario lags behind its American counterparts in terms of data collection, which is the case for Canada in general (this segment of the university workforce is not reported on by Statistics Canada), studies released in 2018 help to paint a clear picture of precarity in the academy in Ontario and the country as a whole (Foster \& Birdsell-Bauer 2018; Shaker \& Pasma 2018; OCUFA 2018). Canadian universities have become entrenched in "academic capitalism," which Slaughter and Rhoades (2005) define as "the involvement of colleges and faculty in market-like behaviours" (37). At 53.6 percent, over half of all faculty 
appointments in Canada are currently contract or sessional (Shaker \& Pasma 2018). In Ontario, that number is said to be at 58 percent (OCUFA 2018). Sessional faculty is defined by Jones \& Field (2014) as "a category of workers who are employed to teach a course and are usually paid on a per-course basis" (14). The average pay of non-tenured faculty members fluctuates in Ontario between $\$ 5,584$ per course at the lowest end of the spectrum and $\$ 9,500$ at the top end (York University Faculty Association 2018). Salary levels are difficult to determine as there is no standard, province-wide consensus on what course load amount equates to a full-time teaching load, nor is there guarantee of a set amount of courses per sessional faculty per term or per academic calendar year (Jones \& Field 2016; Giroux 2014). For contract faculty, job insecurity is ever present (Foster \& Birdsell-Bauer 2018). Thus, such jobs are in stark opposition to tenure-track/stream appointments where candidates enter a probationary period of employment as an Assistant Professor. After this probationary period, a review is conducted of their research, service, and teaching via tenured faculty members and a decision is reached upon whether the candidate will receive tenure/permanent appointment.

The proportion of permanent full-time faculty at Ontario universities has not kept pace with exuberant growth in student enrolment. Each university holds autonomy in terms of employment and budgeting, operating as "autonomous corporations" (Jones \& Field 2014, 5). Undergraduate enrolment in Ontario has grown by 28 percent and graduate enrolment by 31 percent. While the overreliance on sessional faculty is in part attributed to government funding cutbacks, this overreliance is also a by-product of the neoliberal market model with which the university is increasingly aligned (Jones \& Field 2014). The massification of higher education, which has translated into high enrolment rates and increasing tuition, has not translated into better wages and working conditions for the majority of faculty. According to Shaker and Pasma's (2018) report, two thirds of Ontario contract faculty experience stress due to their precarious workplace situations, as well as stress relating to major life events, including difficulty obtaining a bank loan, rental agreement, or mortgage due to unstable and changing work and pay ratios. Changes to OSAP drafted by the Ford administration have effectively eliminated the free tuition program for low-income students (Jones 2019). Under the previous Liberal government led by Kathleene Wynne, OSAP loans were converted into grants to offset Ontario's rising tuition costs. Under the Liberals, students were offered a six-month interest-free "grace-period" upon graduation. However, due to the changes under Doug Ford's government, interest will begin accumulating immediately upon graduation. Severe funding shortfalls and increasing cuts to PSE will not only force Ontario students to make up the operating budget deficits, but will push sessional faculty into worsening labour and financial conditions. Most recently, it was announced by the Ford administration, that university and college funding would become tied to "performance outcomes" that seek to measure how Ontario's 45 PSE institutions conform to metrics, such as student satisfaction. It has been argued that under these performance measures, faculty will be further scrutinized and their academic freedom eroded (Loriggio 2019). This proposed funding shift further entrenches PSE in a neoliberal approach, which, by prioritizing standardization and outcomes, ultimately devalues meaningful engagement, academic integrity, and process quality in the classrooms of Ontario.

Similar to the PSE context, childcare in Ontario is increasingly conceptualized as a privatized service, rather than a social and public good. The consumer model of financing informed by neoliberal choice discourse (Friendly \& Prentice 2009; Richardson et al. 2013) also dominates the childcare landscape in Ontario. It positions parents as individual entities or customers who choose services such as private childcare, the Live-In-Caregiver Program, or regulated or unregulated home- or centre-based childcare. Rather than government investment in a national universal childcare strategy, funding incentives, such as the Canada Child Benefit are primarily allocated to families, who must select their own childcare arrangements, a vast majority of which are unregulated (Richardson et al. 
2013). Moreover, in addition to this market model of childcare, the discursive devaluation of care work is problematic for the advancement of ECEC workforce. In 2007, Ontario became the first province to professionalize the early childhood workforce, establishing the College of Early Childhood Educators (CECE), a self-regulated body for ECEs. The creation of the CECE resulted in increasing professional duties and expectations for ECEs and childcare workers, which have not materialized into higher wages and improved working conditions (Halfon \& Langford 2015). While childcare fees in Ontario have skyrocketed, ECEs wages have not increased and remain at an average of $\$ 16.35$ an hour (AECEO 2016). In this way, the lack of federal/provincial policy, planning, and funding has caused what Ferns and Beach (2015) refer to as a staff/program divide as parent fees continue to rise and ECE's responsibilities increase, yet ECE wages and working conditions fail to reflect the value of their work. ECEC continues to be conceptualized as a basic commodity rather than as a public or social good (Friendly \& Prentice 2009; Powell et al. in press). The lack of a national childcare strategy with a shared social responsibility is strongly correlated with gendered norms of labour, as approximately 97 percent of ECEs are women (Bezanson 2017). ECEC continues to be discursively articulated as care work (a devalued conceptualization within a neoliberal discourse) as opposed to education that is funded and conceptualized as a social responsibility, despite the ethical value and professionalization of the ECEC workforce and decades of research asserting the importance of the early years. This compounds the marginalization of ECEs and impacts their material realities (Powell et al. in press).

In 2010, Ontario's Education Act was amended to align with changes enforced with the roll out of Full Day Kindergarten (FDK) (AECEO 2015). FDK is a publicly funded initiative that allows four- and fiveyear-olds across Ontario to attend kindergarten in publicly funded school boards with one Ontario Certified Teacher (OCT) and one ECE. ECEC thus experienced an administrative and discursive shift, as it became part of the Ministry of Education rather than the Ministry of Children and Youth (AECEO 2015). This shift was accompanied by an increased public awareness of and interest in the importance of early childhood learning in lifelong educational outcomes. Indeed, while ECEs working alongside OCTs should have reinforced the professional status of ECEs, and public funding could help alleviate the factors that contribute to challenging working conditions and low wages, feedback from the sector continues to demonstrate that this has not been realized. ECEs working within the Ontario public school system continue to experience marginalization and devaluation by way of poor remuneration, a lack of decent work, and a lingering lack of recognition of their value and professional status (AECEO 2016). While there are some visible factors that contribute to the ongoing precarity of ECEs within the FDK system, such as different qualifications and curricular approaches (Underwood et al. 2016) and fragmented unionization (Gananathan 2015), more important are the invisible issues, such as public opinion, power imbalances, and the devaluation of care work (AECEO 2016). While providing opportunity for a collaboration of education and care (which continues to develop and unfold in kindergarten classrooms across Ontario), the enactment of FDK and inclusion of ECEs in the publicly funded education system has done little to improve precarity and has only somewhat reinforced the professional status of ECEs.

While the FDK initiative has the potential to enhance the professionalization of ECEC, teacher and ECE roles are highly stratified (Gibson \& Pelltier 2016). The dichotomized role of Registered Early Childhood Educators (RECEs) and OCTs is comparable to that of sessional faculty and tenure track faculty. While teachers are paid substantially more and their salary increases incrementally with each year of service, RECEs' pay remains relatively stagnant (Gananathan 2015). The precarious status of RECEs within publicly funded school boards is marked by their hourly contracts, unpaid summer vacation months, and less job security, as their job permanence depends on enrolment rates of four- and five-year-olds. Finally, there 
is the reliance on ECEs to take on split shifts between different schools, requiring them to travel from one location to another (often far apart from one another) in order to make full-time hours, whilst losing break and planning times (Gananathan 2015; Moss 2006). This hierarchical relationship is noted in RECE testimonies of feeling undervalued as an assistant to the teacher; having to share space; experiencing differences in working conditions, pay, and prestige; and experiencing an overall lack of respect from colleagues and parents (Gibson \& Pelletier 2016). A professionalization gap exists for ECEs, whereby on the one hand ECEs have professional status allocated by representation in a regulatory body. However, on the other hand, ECEs continue to receive low wages accompanied with higher expectations, including an annual CECE membership fee of $\$ 160$ a month, which now surpasses the Ontario College of Teachers membership fee (CECE 2019).

The devaluation of care work, which is overwhelmingly performed by women and women from racialized communities (Child Care Human Resources Sector Council 2007), is also visible in the way ECEC is professionalized. When contemplating the meaning of professionalism in the neoliberal social political context such as "Doug Ford's Ontario," it is important to be mindful of the mechanisms by which professionalism is constructed: through masculinist power relations dependent on a gendered and racist capitalist system (Osgood 2010). Professionalism in ECEC has also strengthened the market model approach by enforcing government accountability through an audit culture and by, drawing on Foucault, a panoptic "regulatory gaze" (Osgood 2010, 124). Through professionalization, ECEs in Ontario have been subject to increasing scrutiny and masculinist (government) control without better pay and working conditions. Increased government control mechanisms to the ECEC sector have come to light under Ford's leadership, which seeks to implement massive childcare cuts through the discursive "choice" illusion. Currently, provincial cuts to childcare funding have placed over 6,000 subsidized childcare spots at high risk in the City of Toronto alone (Rider
2019). The cuts were overshadowed by the Ford government's Childcare Access and Relief from Expenses (CARE) tax credit announcement in the 2019 budget. The tax credit claims to provide parents and families with increased choice in determining the childcare services that work best for their situation as individual agents, rather than as a collective social good. Yet, the CARE tax rebate will not offset the high cost of childcare in Ontario, nor will it provide more regulated childcare spaces in the province (Gray 2019). This individual approach to childcare policy further entrenches Ontario in a neoliberal market model, while in no way addressing the ongoing devaluation of care work and its implications on women, in particular racialized women, who take on paid care work responsibilities outside of the home.

\section{Feminist Political Economy}

This article draws on a FPE framework to conceptualize work as more than just paid labour, but instead as including unwaged labour, precarious work, social reproduction, and domestic labour (Acker 2011; Armstrong \& Connelly 1989; Benzanson 2006; Lewchuk et al. 2015). FPE underlines the gendered, racialized, and social-economic intersectionalities of oppression that in turn frame women's experiences, options, and opportunities (LeBaron \& Roberts 2010). In keeping with FPE, we have attempted to provide a gendered, classed, and raced analysis of both PSE and ECEC to understand how institutional, social, and political-economic contexts frame women's work. We agree with the conceptualization of care and education (both in the early years and PSE sectors) as social reproduction: the essential work that must be undertaken in order for society to thrive and continue as women work to ensure the reproduction of the species and the labour force (Bakker 2007; Bezanson 2018). As Bezanson (2018) describes: "Capital, and, in particular, its neo-liberal variant, does not care who undertakes the labours that create, sustain, maintain, reproduce, and socialize workers and norms of employment, but it requires that it be done as cheaply as possible" (172). As such, care and education as social reproduction exist in constant 
tension with a neoliberal economic system and the discourses it produces/reproduces (for example, stories that prioritize individualism, rationality, efficiency) and are bound within this system to rely upon (predominantly racialized) women who are thus undervalued and underpaid for their labour.

The rise in sessional faculty has been particularly devastating for women, racialized, and Indigenous scholars (Sensoy \& DiAngelo 2017; Wane \& Abawi 2018). The majority of sessional faculty are women, one half to one third of which holds a doctoral degree. However, white women continue to fare better than racialized and Indigenous women in the Ivory Tower. According to the most recent census data available, fewer than 4 percent of university professors identify as racialized or "visible minority" women (Statistics Canada 2019) and only 1.4 percent of professors self-identify as Indigenous (Foster \& BirdsellBauer 2018; Henry et al. 2017); the number of female Indigenous academics is unknown. Racialized and Indigenous women are concentrated in sessional academic work across Ontario and Canada, while tenure-track positions are largely held by white males (Abawi 2018; Sensoy \& DiAngelo 2017). These figures are in stark contrast to the increasing demographics of racialized and Indigenous students on Canadian campuses (Henry et al. 2017) and decades of employment equity initiatives to combat institutionalized white privilege in academia (James 2009; 2011). Moreover, tenured/tenure-track racialized and Indigenous women are often expected to take on additional unpaid roles, such as mentorship to racialized students, guidance, and committee representation, all whilst conforming to the status quo of white-dominated departments (Matthew 2016; Nair 2014). The overrepresentation and dominance of white male norms and subjectivity in higher education further frames what the academe legitimizes as academic research, norms, and credibility (Reid \& Curry 2019). Thus white-dominated institutions embed and reproduce whiteness through curriculum, institutional culture, validation of knowledge and perspectives, whilst claiming to be race-less and neutral spaces (Bonilla-Silva 2006; Sensoy \& DiAngelo 2017).
When contemplating the myriad ways that social reproduction and unpaid and devalued labour implicate ECEC work, it is important to consider that policies and social norms framing ECEC and care work in general are based on privatized, feminized welfare issues rather than ethical work deserving of public funding (Bezanson 2017; Ferns \& Beach 2015; Langford et al. 2017). The devaluation of female-dominated care work is compounded by the patriarchal social conservative notion that looking after young children is a natural inclination for women, and thus does not warrant higher wages (Halfon \& Langford 2015; Jones, Richardson, \& Powell 2019; Moss 2006). According to the Association of Early Childhood Educators Ontario (AECEO) Pre-Budget Submission Report, 24 percent of RECEs working in licensed childcare centres earn $\$ 15$ an hour or less, another 45 percent earn between $\$ 15$ and $\$ 20$, and a significant 67 percent of other program staff working in licensed child care centres earns \$11-\$15 per hour (AECEO 2018). While Ontario is lacking sufficient workforce data, national and international comparators reinforce experiential knowledge that care labour continues to be downloaded to racialized women who are overrepresented in low-paying positions (Powell et al., in press). Much like the corporate university where the financial onus of higher education is placed on the individual consumer, whereby a degree is purchased as a commodity, ECEC also operates through a marketized corporate approach. Canada lacks a national childcare strategy, as childcare legislation is left to the discretion of the provincial governments. The absence of federal government oversight of childcare policy-making, as well as the erosion of funding, has in turn exacerbated the mass privatization of childcare services. The market model of childcare (Halfon \& Langford 2015) is most evident in the locations where childcare services are established, locations that are largely based on financial incentives rather than accessibility, community, and family needs (Bezanson 2017; Ferns \& Beach 2015).

Thus far, we have considered how our education and care "systems" are both a result of the current social, political, and economic context (increasingly neoliber- 
al in our circumstance) and how they also then reproduce these same trends. In this section, we have presented a brief macro view of the two sectors, demonstrating that our current neoliberal context is increasingly moving education to the margins, with women and racialized and Indigenous women the most marginalized. In turn, we considered how being employed in these unstable sectors of the labour market has a similarly marginalizing affect on women, and racialized women in particular, who are the people caring for children and teaching the majority of undergraduate students. Just as ECEC is gendered and racialized, so is the precarious professoriate. Adopting this perspective allows us to examine the possibilities and constraints for racialized women in different places in the feminized educational labour market. This approach contrasts with and deconstructs the neoliberal approach regarding the dominant meritocratic discourse that "simply trying harder will allow you to be financially rewarded." Our analysis thus demonstrates how work, gender, and race interact to impact people's choices and opportunities. In keeping with a FPE approach, we turn now to the section of this paper that undertakes a micro view and share our lived experience as another way to make this social reality visible.

\section{Personal Narratives}

\section{Zuhra Abawi}

I have been fortunate to hold various roles in education, as an RECE, an OCT, and sessional faculty member. I self-identify as a white-coded, racialized, cisgender woman; my father is from Afghanistan and my mother is a Scottish-Canadian settler. My journey in education started out many years ago when I began volunteering at my old elementary school. I had completed my undergraduate degree and had two young children; I had thought about being a teacher but was not sure if it was for me. I took a position as a lunchroom supervisor shortly after I began volunteering. I enjoyed being in the classroom in a K-8 school; I would stay late sometimes after my shift was over just to observe and volunteer and see what teaching was all about. I enrolled in Sheridan
College's Early Childhood Education program and, since I already had a degree, I was able to fast-track the program and apply to teacher's college the following year (as I had already missed the application deadline for the current year). My plans fell into place; I became an ECE and received admission to York University's Bachelor of Education program in the Primary and Junior divisions. I thoroughly loved teacher's college in particular, as I had wonderful professors who exposed me to a wealth of ideas. I could not get enough of the education program and continued my journey to complete my Master of Education degree. I was put on the Toronto District School Board (TDSB) ECE supply list while in teachers' college and began to supply immediately while working through my master's degree. After completing my master's, I felt content. With the degree, I knew that I could become an administrator down the road and I was offered an interview for a full-time permanent position as a Designated Early Childhood Educator (DECE) at the Peel District School Board. Being a single parent at the time, it was an offer I could not turn down. I got the job.

I started my job as an RECE in the FDK program in 2014, the very first year that the province introduced the program. My oldest daughter was also coincidentally starting FDK as well. While working with my teaching partner, I noticed the divide in status, working conditions, and pay. Although my education and qualifications exceeded that of my OCT teaching partner (I was also an OCT), she made twice as much as I did and had an hour of paid lunch a day, in addition to one or two planning periods each day. I was offered no planning time, nor input on report cards or any assessments. I also had limited contribution to curriculum implementation. I had a half-hour of unpaid lunch, which was always held up while waiting for the lunchroom supervisor to come to the classroom, or by a situation that had escalated such that I could not leave for my lunch on time. In the afternoons I was meant to receive a fifteen-minute break, which I seldom received. I decided to apply to the Peel Occasional Teacher (OT) roster and was successful. 
Following my full year as an ECE, I transitioned to the role of an OT and was admitted to OISE/University of Toronto for my doctorate. Throughout my doctoral work I completed OT and Long Term Occasional Teacher (LTO) positions and moved up to get on the LTO list. During my final year of doctoral work, I began teaching in higher education at Ryerson University's School of Early Childhood Studies, Western's Faculty of Education, and the Ontario Teacher Education program at Niagara University. While working as a sessional faculty member at these institutions, I could not help but notice the various parallels between my time as an ECE and my position as a sessional lecturer. I began to jot down my ideas. First, I made the connection between the two in terms of pay: sessional lecturers are paid on a percourse basis, in opposition to tenured faculty who are paid salaries; ECEs similarly are paid per hour rather than by annual salary (as teachers are paid); ECEs are not paid over the summer months, while teachers are; ECE jobs are not secure and are dependent on enrolment, as in the case of sessional faculty, whilst teachers are permanent, as are the tenured professoriate. Second, I noted that sessional faculty are left out of departmental meetings and planning committees, just as ECEs are left out of most assessment and programming decisions made by teachers. Finally, in addition to the two-tiered system of status and prestige sessional faculty and ECEs experience in relation to their tenured and teacher counterparts, there are increasing expectations of both workers. Sessional faculty are paid significantly less for increasing teaching loads and responsibilities such as meeting with students and mentoring with limited space; many sessionals operate out of one office. ECEs are expected to complete more work and professional duties, such as Continuous Professional Learning, to maintain their RECE membership, although this workload does not lead to greater pay or status. It was effectively these parallels that sparked my interest in analyzing the similarities of these two types of education work that are both heavily situated along racialized and gendered power relations. The instability of sessional contract work was too much of a strain on my family life, so I decided to return to the board and I currently teach Grade 7.

\section{Rachel Berman}

During the time I was working on my dissertation at a university in Ontario in the 1990s, I had a baby and began teaching on contract at a number of different institutions. My doctoral committee didn't like either of those additions to my life, as they believed they both took me away from completing my dissertation in a timely manner. However, I wanted to have a child and I also believed I would never land a fulltime job in academia with no teaching experience other than having worked as a teaching assistant who graded papers. Unable to afford childcare except one day a week, my mother and mother-in-law stepped in to care for their grandchild one day a week each. On the weekends, my former partner took on solo parenting duty. Thus, as my child turned one, I had 4-5 days a week to engage in studies and work. I became an "itinerant scholar," a term someone mentioned to me in the 1990s for sessionals who taught at multiple institutions. I felt my prospects for full-time work were rather grim as I had heard stories of PhDs at the time, particularly in the humanities, not landing tenure track positions, and would often "joke" that the only questions I'd be asking after I graduated would be if people wanted fries with their burger. I held contract teaching positions at McMaster in Hamilton, Ontario, York University in the former North York, and Ryerson University in the middle of downtown Toronto, as well as an outpost of Georgian College in Shelburne, Ontario.

Shortly after completing my dissertation, I was interviewed and hired into a tenure track position at Ryerson University, into a department where I had not been a contract faculty member. Apparently there had been 25 applications submitted to the department, a department that had not done much tenure track hiring in a long time (and indeed Ryerson University still has one of the worst faculty-to-student ratios in the province of Ontario). My partner at the time was only trained to work in Ontario and after we separated some years later I could not, given our custody arrangement, work outside the city. So, I was very fortunate to be hired into a tenure track position and into such a position in Toronto. When I chaired our 
department's hiring committee recently, we received well over 80 applications for one tenure track position and interviewed many qualified people. I was also part of the full-time faculty negotiation team that engaged in collective bargaining with the university administration, and have seen first-hand that faculty associations and the myriad of unions connected to the PSE sector must work together if we hope to change the material conditions of precarious faculty members. I met Zuhra Abawi, the first author of this paper, when we became acquainted after I visited her class for a teaching assessment while she was teaching in the department on contract. I met Alana Powell, the third author of this paper, while she was an MA student in the program where I serve as Director.

\section{Alana Powell}

As a proud ECE, I was thrilled to accept my first position at a non-profit community-based childcare centre in Toronto. In fact, I (a privileged white, cis woman and settler in Ontario) felt incredibly grateful to be offered what is considered a high salary (given, of course, the context of the ECEC sector). Despite being thoroughly aware of the challenges ECEs faced with remuneration, I thought perhaps this might be a liveable wage. Perhaps, even, I could leave my part-time bar job. This, however, was certainly not the case. While I can sincerely say "I was one of the lucky ones," I continued to hold a parttime job, working weekends and evenings to ensure that I could make ends meet and pay back student loans, and yet I could still not save or plan for my future. Despite this, I worked (hard) and gave my program, the families, and my community my best.

Over time, I began to recognize the depth to which ECEs are undervalued, the grave implications this has on women, the early-years workforce, children, families, society, and the incredible injustice that occurs each day this system continues. I saw racialized women exploited in low-paying temporary positions, unable to access the benefits associated with full-time salaried positions. I saw how our supervisor struggled to balance parent fees and wages, while families were often unaware of the precarity the staff faced. I saw my colleagues purchase materials out of pocket and work on the weekends. I stayed after hours to finish documentation. I created materials for our program on the weekends. I worked on curriculum through my lunch break. Yet, I was still the "lucky one" who had access to health benefits, paid sick days, and professional development. As a result of my noticing and attending to the unjust system, I left my coveted position and returned to school to complete my MA. I hope(d) to contribute to efforts to disrupt the neoliberal context that positions care work as an individual/private/women's responsibility.

While working towards my MA, I was in an incredibly privileged position to accept work as a contract/sessional lecturer at an Ontario college in an ECE diploma program. I thought, and continue to think, that post-secondary faculty are valuable educators, who are uniquely positioned to support (in this case) predominantly young women as they transition into the workforce. As well, it was my perhaps naïve perspective that post-secondary educators were appropriately compensated for their work. While this is arguably truer for full-time faculty, as a contract lecturer I found the precarity and devaluation shocking and oddly similar to my experience as an ECE. I continued to work on weekends and evenings - for example, grading papers, responding to student emails, preparing for lectures. It was explained to me that planning time was accounted for in my hourly wage, which paid me exclusively for the hours I lectured. However, in no way was this sufficient given the frequency and amount of work that occurred outside of the classroom. Beyond remuneration, there were certain other challenges I faced as a contract lecturer, for example, inconsistent access to space to meet with students, no paid office hours, limited storage space on campus, covering the cost of Microsoft Word and other software programs independently, and lack of access to professional learning and important meetings. Overcoming these challenges to ensure I was providing my students the most meaningful learning required my independent problem-solving and creativity, with a general lack of institutional support. ${ }^{1}$

Issue $40.1 / 2019$ 
The very serious problem here, so eerily similar to my experience as an ECE, is that it was me and my students who were affected by these constraints. The neoliberal context that entrenches larger class sizes, notions of efficiency, and precarity in employment ultimately means that individual employees must tighten their bootstraps and just "work harder" (for less). Students, and children, are then relying upon overworked, undervalued, and underappreciated educators who continue to try to provide the space, time, and relationships within which we know learning occurs. As our economic and education systems continue to shift deeper into a neoliberal approach, space, time, relationships, and value shift further into the distance and educators further into precarity. It is unacceptable to continue to ask individual educators to do more with less. Education from the margins creates a future that is marginal at best.

\section{Discussion and Conclusion}

Social public goods, such as affordable and high-quality ECEC and PSE, have been diluted and ultimately eroded by the marketization of neoliberalism. As state responsibilities continue to be offloaded from the state to the individual, Ontario and Canada's claims to be a social-welfare society can no longer be substantiated. Record-high childcare and tuition costs in Ontario, in conjunction with the normalization of precarious employment, not only limited to sessional faculty and ECEs but to the general population as well, are ways in which we see the neoliberal approach influencing individual's well-being and social sustainability. Increasingly, Ontarians are finding themselves trapped in precarious or non-standard contract and temporary work with low pay while servicing higher student loan payments and childcare fees (OECD 2017). According to an Organization for Economic Cooperation and Development (OECD) 2017 report, employment quality in Canada is at a 25 -year low. The report specifically drew attention to Southern Ontario workers, noting that less than half of working adults have full-time, permanent jobs (OECD 2017).
Employment precarity does not affect all Ontarians equally, as racialized people, particularly racialized women, fare the worst in the labour force. Ontario PSE and ECEC are no exception to this rule. While universities across the province have drafted equity policies to address discrepancies between predominantly white, male, tenure-track professors and marginalized faculty, the general unwillingness of departments to collect faculty demographic data has rendered the majority of these policies redundant (Abawi 2018; Sensoy \& DiAngelo 2017). Moreover, universities continue to operate as neutral spaces whereby racism ceases to exist; this denial increasingly oppresses racialized and Indigenous faculty by glossing over lived experiences (Ahmed 2012; Henry et al. 2017). Common perceptions of sessional faculty, including the myth that they are on contract by choice while working as full-time professionals, are patently untrue. As Foster and Birdsell-Bauer (2018) point out, more than half of sessional faculty are aspiring to a tenure-track position.

The lack of purposeful data collection in the ECEC sector and in PSE is an ongoing concern, as it restricts the possibility of illustrating the current context and helping illuminate a path forward. The Child Care Human Resources Sector Council, which had started to make some progress in this regard, lost its core funding due to changes made by Stephen Harper's Conservative government in 2013 and was dissolved. For equity policies to materialize, it is critical for Ontario universities to make available more detailed data-based reports that outline data collection processes and methodology. While there has been some progress made by universities in terms of their commitment to data collection, most notably the partnership between Statistics Canada and university and college academic staff system, universities continue to be divided by faculty and managers, and further divided between tenure-track and sessional faculty (Abawi 2018; Foster \& Birdsell-Bauer 2018). Despite increasing national interest in the early years, there continues to be a "data drought," especially pertaining to the workforce. ECEC sectoral data collection is negligent and fragmented and in no way addresses the 
precarity and marginalization experienced by the (predominantly female) workforce. While anecdotal claims are made about the racialization of low paying jobs in the sector, Ontarians lack the evidence to substantiate these claims and adequately begin to address the systemic racism that contributes to the current situation.

While we have highlighted the grim reality throughout this paper, it is important, in keeping with a FPE approach, to also acknowledge the power of educators who are pushing back against encroaching neoliberal thinking. Numerous faculty strikes have transpired across Ontario campuses, most notably the three-and-a-half-month strike at York University in 2018. The Canadian Association of University Teachers launched their 12th Fair Employment Week in October 2019 to raise awareness both on and off campuses of the challenges faced by contract faculty. These acts of solidarity and collectivity are essential to resisting further marketization of universities and the disjointing of academic freedoms. Without allyship between tenure-track and sessional faculty, however, these acts remain limited (Betensky 2017; Hearn 2010). The ECEC sector is also becoming increasingly active. Led by the AECEO, ECEs across Ontario are taking on leadership roles in political action through the Decent Work and Professional Pay campaign. What is most critical in this work is that the voices of ECEs are at the centre; it is the marginalized themselves who are highlighting the inequities and suggesting a path forward. It will continue to be essential that those who are most affected by precarity are guiding the movement against it. Similar to post-secondary educators, allyship is critical, as ECEs seek the support of OCTs, administrators, community members, and, most significantly, parents in order to persuade change at the policy and funding level. Beyond their inherit value, both OCTs and ECEs are critical for social reproduction and the success of Ontario's future wellbeing. To care for and educate citizens well, Ontario requires educators who are valued, diverse, well-compensated, and able to access decent work. We must move away from a market approach to education and create space and time for educators in the PSE and ECEC sectors to engage, be present, and create learning with children and adults that ensure our population is cared for.

\section{Endnotes}

1. It is very important that I acknowledge the support I received from my colleagues throughout this experience. Despite institutional constraints, individual colleagues were quick to respond with support, guidance, and assurance. In no way do I mean to devalue their individual contributions to my success and well-being. 


\section{References}

Abawi, Z. 2018. "Factors and Processes of the Racialization of the Canadian Academe." Canadian Journal for New Scholars in Education 9 (1): 85-95.

Acker, J. 2011. "Women, work, \& politics: The political economy of gender inequality." Contemporary Sociology: A Journal of Reviews 40 (5): 596-597.

Ahmed, S. 2012. On Being Included: Racism and Diversity in Institutional Life. Durham \& London: Duke University Press.

Armstrong, P. \& Connelly, M. P. 1989. "Feminist Political Economy: An Introduction." Studies in Political Economy (30): 5-12.

AECEO, Association of Early Childhood Educators Ontario. (2018). AECEO Pre-Budget Submission. Retrieved from: https://d3n8a8pro7vhmx.cloudfront.net/aeceo/pages /2325/attachments/original/1517434530/AECEO_2 018_Pre-budget_submission.pdf?1517434530.

2016. "I'm more than 'just' an ECE": Decent Work from the perspective of Ontario's early childhood workforce. Retrieved from: https://www.childcarecanada.org/sites/default/files/I $\mathrm{m} \% 20$ more\%20than\%20just\%20an\%20ECE.pdf.

2015. "Full Day Kindergarten." Retrieved

from: https://www.aeceo.ca/tags/fdk

Bakker, I. 2007. "Social Reproduction and the Constitution of a Gendered Political Economy." New Political Economy 12 (4): 541-556.

Betensky, C. 2017. “'Tenured Allies' and the Normalization of Contingent Labor: It's Time for Tenured Faculty to Address the Elephant in the Room." American Association of University Professors. Retrieved from: https://www.aaup.org/article/tenured-allies-and-
normalization-contingent-labor\#.XPLaxDLMz_Q

Bezanson, K. 2018. "Feminism, Federalism and Families: Canada's Mixed Social Policy Architecture." Journal of Law and Equity 14 (1): 169-197.

2017. "Mad Men Social Policy: Families, Social Reproduction, and Childcare in a Conservative Canada." In Caring for Children Social Movements and Public Policy in Canada, edited by R. Langford, S. Prentice, \& P. Albanese, 9-36. Vancouver, BC: UBC Press.

. "Gender and the Limits of Social Capital." Canadian Review of Sociology 43 (4): 427-443.

Bonilla-Silva, E. 2006. Racism without Racists: Colorblind Racism and the Persistence of Racial Inequality in America (4th ed.). Lanham, MD: Rowman and Littlefield.

CECE (College of Early Childhood Educators). 2019. CECE Registration FAQs. Retrieved from: https://www.college-ece.ca/en/Become-AMember/Registration-Process

Childcare Human Resources Sector Council. 2007. Career Promotions and Recruitment Strategy Project: Executive Summary. Ottawa: Child Care Human Resources Sector Council.

Faucher, K. 2014. "Alienation and Precarious Contract Academic Staff in the Age of Neoliberalism." Confero 2 (1): 35-71.

Ferns, C. \& Beach, J. 2015. "From Childcare Market to Childcare System." Our Schools, Our Selves 24 (4) issue 120: 43-62. Retrieved from:

https://www.policyalternatives.ca/sites/default/files/up loads/publications/National\%20Office/2015/09/OS1 20_Summer2015_Child_Care_Market_to_Child_Ca re_System.pdf.

Foster, K. \& Birdsell-Bauer. 2018. Out of the Shadows: Experiences of Contract Academic Staff. Opportunity, 
Security, Respect. Canadian Association of University Teachers (CAUT). Retrieved from:

https://ocufa.on.ca/assets/2018-02-15-OCUFA-

Faculty-at-Work-response.pdf.

Foster, K. 2016. "Precarious Contract Faculty in Nova Scotia Universities." Canadian Association of University Teachers. Retrieved from:

http://ansut.caut.ca/wp-

content/uploads/2016/09/ANSUT-Precarious-U-

Final -Report.pdf.

Friendly, F. \& Prentice, S. (2009). About Canada: Childcare. Fernwood Publishing: Winnipeg.

Gananathan, R. 2015. "Implications of Full Day Kindergarten Program Policy on Early Childhood Pedagogy and Practice." International Journal of Child Care and Education Policy 5 (2): 33-45.

Gibson, A. \& Pelletier, J. 2016. "Can We Work Together? Preliminary Findings from an Examination of ECE and Teacher Dynamics in FullDay-Early-Learning Kindergarten.” Retrieved from: http://www.oise.utoronto.ca/atkinson/UserFiles/File/ SI2011_Poster_ECEandKteacher.pdf.

Giroux, H. A. 2014. Neoliberalism's War on Higher

Education. Chicago, IL: Haymarket Books.

Gray, J. 2019. "Ontario child-care tax credit to help few low-income families, watchdog says." The Globe and Mail. Retrieved from:

https://www.theglobeandmail.com/canada/articleontario-child-care-tax-credit-to-help-few-lowincome-families/

Halfon, S. \& Langford, R. 2015. "Developing and Supporting a High-Quality Child-Care Workforce in Canada: What are the barriers to change?" Our Schools, Our Selves 24 (4): 131-143.

Hearn, A. 2010. Exploits in the "Undercommons." In Academic Callings: The University We Have Had, Now Have, and Could Have, edited by J. Newson and C. Polster, 205-211. Toronto: Canadian Scholars Press Inc.

Henry, F., Dua, E., Kobayashi, A., James, C., Li, P., Ramos, H. \& Smith, M. 2017. The Equity Myth: Racialization and Indigeneity at Canadian Universities. Vancouver: University of British Columbia Press.

James, C. E. 2011. "Welcoming 'Visible Minorities': Paradoxes of Equity Hiring in Canadian Universities. Federation for the Humanities and Social Sciences." Retrieved from: http://www.ideasidees.ca/blog/welcoming-visible-minoritiesparadoxesequity-hiring-canadian-universities.

. 2009. "It Will Happen without Putting in Place Special Measures: Racially Diversifying Universities." In Racism in the Canadian University: Demanding Social Justice, Inclusion, and Equity, edited by Henry et al., 128-159. Toronto, ON: University of Toronto Press.

Jones, A. 2019. "Ontario Announces Tuition Cut, Eliminates Free Tuition for Low-Income Students." CTV News. Retrieved from: https://toronto.ctvnews.ca/ontario-announcestuition-cut-eliminates-free-tuition-for-low-incomestudents- 1.4257256

Jones, G. A. \& Field, C. 2016. "Survey of Sessional Faculty in Ontario Publicly-Funded Universities." Centre for the Study of Canadian and International Higher Education at OISE-University of Toronto, 34.

.2014. "Increasing Access to Higher

Education: A Review of System-Level Policy Initiatives." In International Conference on Access Policy of Higher Education: Conference Proceedings, 52-66. Beijing: Beijing Normal University.

Jones, M., Richardson, B. \& Powell, A. 2019. "Reconceptualizing Our Work: The Connection between ECE Students and Political Action." Journal of Childhood Studies 44 (1): 123-133. 
doi:10.18357/jcs.v44i1.18782.

Kirmse, N. 2018. "Analysis: Daycare Fees Continue to Rise Across Canada." CTV News. Retrieved from: https://www.ctvnews.ca/features/analysis-daycare-feescontinue-to-rise-across-canada-1.3940099.

Langford, R., Albanese, P., Bezanson, K., Prentice, S., Richardson, B., Banks, M. \& Powell, A. 2017. "Caring About Care: A Closer Look at Care in Canadian Childcare." Project Bulletin \#1. Retrieved from:

https:/www.oise.utoronto.ca/atkinson/UserFiles/File/ Resources_Topics/Stuff/Caring_about_Care_Project_ Bulletin_1.pdf

Lewchuck, W., Lafleche, M., Procyk, S., Cook, C., Dyson, D., Goldring, L., Lior, K., Meisner, A., Shields, J., Tambureno, A. \& Viducis, P. 2015. "The Impact of Employment Precarity on Individuals, Households and Communities - and What To Do About It." Poverty and Employment Precarity in Southern Ontario. Retrieved from: https://pepso.ca/documents/precarity-penalty.pdf

LeBaron, G. \& Roberts, A. 2010. “Toward a Feminist Political Economy of Capitalism and Carcerality." Signs 36 (1): 19-44.

Loriggio, P. 2019. "College and university funding tied more to performance”. Global News. Retrieved from:

https://google.ca/amp/s/globalnews.ca/news/5158243 /college-and-university-funding-tied-more-toperformance/amp/

MacDonald, L., Richardson, B. \& Langford, R. 2015. "ECEs as Childcare Advocates: Examining the Scope of Childcare Advocacy Carried Out by ECEs from the Perspective of Childcare Movement Actors in Ontario and Manitoba." Canadian Children 40 (1): 100-110.

Mahboubi, P. 2018. "What's Wrong with Ontario's Child-Care Plan?" The Globe and Mail. Retrieved from:

https://www.theglobeandmail.com/business/comment ary/article-whats-wrong-with-ontarios-child-careplan/.

Matthew, P.A. 2016. "What is Faculty Diversity Worth to a University?" The Atlantic. Retrieved from: https://www.theatlantic.com/education/archive/2016/ 11/what-is-faculty-diversity-worth-to-auniversity $/ 508334 /$.

Moss, P. 2006. "Structures, Understandings and Discourses: Possibilities for Re-envisioning the Early Childhood Worker." Contemporary Issues in Early Childhood 7 (1): 30-41.

Muzzin, L. 2008. "How Fares Equity in an Era of Academic Capitalism? The Role of Contingent Faculty." In The Exchange University: The Corporatization of Academic Culture, edited by A. Chan et al., 105-124. Vancouver: University of British Columbia Press.

Muzzin, L. \& Meaghan, D. 2014. "Public Colleges and Democracy." The Innovation Journal: The Public Sector Innovation Journal 19 (1): 1-14.

Muzzin, L. \& Limoges, J. 2008. “'A Pretty Incredible Structural Injustice' Contingent Faculty in Canadian University Nursing." In Whose University Is It, Anyway? edited by A. Wagner, S. Acker \& K. Mayuzumi, 157-172. Toronto: Sumach Press.

Nair, S. 2014. "Women of Color Faculty and the 'Burden' of Diversity." International Feminist Journal of Politics 16 (3): 497-500.

OCUFA. 2018. "Response to the Faculty at Work. Ontario Confederation of University Faculty Association (OCUFA).” February 2018. Retrieved from: https://ocufa.on.ca/assets/2018-02-15OCUFA-Faculty-at-Work-response.pdf

OECD, 2017. "How's Life in Canada?" Retrieved from: https://www.oecd.org/statistics/Better-Life- 
Initiative-country-note-Canada.pdf

Osgood, J. 2010. "Reconstructing professionalism in ECEC: the case for the 'critically reflective emotional professional.'” Early Years 30 (2): 119-133.

Pittman, C. T. 2010. "Race and Gender Oppression in the Classroom: The Experiences of Women Faculty of Color with White Male Students." Teaching Sociology 3 (8): 183-196.

Powell, A., Langford, R., Bezanson, K., Prentice, S. \& Albanese, P. In press. "Who Cares for Carers? How Discursive Constructions of Care Work Marginalized Early Childhood Educators in Ontario's 2018 Provincial Election." Contemporary Issues in Early Childhood.

Reid, R.A. \& Curry, T.A. 2019. “The White Man Template and Academic Bias." Inside Higher Ed. Retrieved 11, October, 2019 from: https://www.insidehighered.com/advice/2019/04/12/ how-white-male-template-produces-barriersminority-scholars-throughout-their

Richardson, B., Langford, R., Friendly, M. \& Rahaula, A. 2013. "From Choice to Change: An analysis of the 'Choice' Discourse in Canada's 2006 federal Election." Contemporary Issues in Early Childhood 14 (2): 155-16.

Rider, D. 2019. "Doug Ford's Cuts Put over 6,000 Subsidized Daycare Spaces at Risk, Toronto Warns." Toronto Star. Retrieved from: https://www.thestar.com/news/city_hall/2019/05/02/ doug-ford-government-child-care-cuts-will-hittoronto-hard-city-manager-warns.html

Sensoy, O. \& DiAngelo, R. 2017. “'We Are All for Diversity, But...': How Faculty Hiring Committees Reproduce Whiteness and Practical Suggestions for How They Can Change." Harvard Educational Review 87 (4): 557-580.

Shaker, E. \& Macdonald, D. 2011. "Under Pressure:
The Impact of Rising Tuition Fees on Ontario Families." Canadian Centre for Policy Alternatives.

Shaker, E., MacDonald, D. \& Wodrich, N. 2014. "Degrees of Uncertainty: Navigating the Changing Terrain of University Finance." Canadian Centre for Policy Alternatives.

Shaker, E. \& Pasma, C. 2018. "Contract U: Contract faculty appointments at Canadian Universities.” Canadian Centre for Policy Alternatives.

Slaughter, S. \& Rhoades, G. 2005. Academic Capitalism and the New Economy: Challenges and Choices. Baltimore, MD: The John Hopkins University Press.

Statistics Canada 2019. Tuition Fees for Degree Programs, 2018-2019. Retrieved from: https://www150.statcan.gc.ca/n1/dailyquotidien/180905/dq180905b-eng.htm

Underwood, K., Santo, A. D., Valeo, A. \& Langford, R. 2016. "Partnerships in Full-Day Kindergarten Classrooms: Early Childhood Educators and Kindergarten Teachers Working Together." Canadian Children 41 (1): 36.

Wane, N., \& Abawi, Z. 2018. "Disposable Academics: Neoliberalism, Anti-Intellectualism and the Rise of Contingent Faculty in the Canadian Academy." In Contextualizing and Organizing Contingent Faculty: Reclaiming Academic Labour in Universities, edited by I. Munene, 207-218. Lanham, MD: Lexington Books-Rowman \& Little.

York University Faculty Association. 2018. Collective Agreement between YUFA and YUBG, 2018-2021. Retrieved from: https://www.yufa.ca/wpcontent/uploads/2019/04/Collective-Agreement-Part1.pdf. 